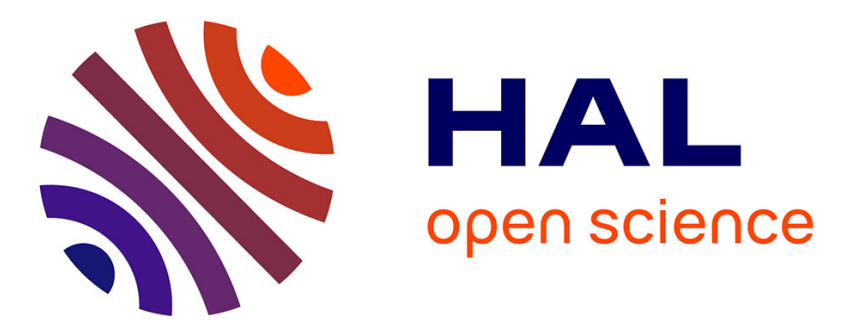

\title{
Biological effects of double-walled carbon nanotubes on the innate immune system: An in vitro study on THP-1 human monocytes
}

Samir Dekali, Christine Bachelet, Séverine Maunoir-Regimbal, Emmanuel Flahaut, Jean-Claude Debouzy, David Crouzier

\section{To cite this version:}

Samir Dekali, Christine Bachelet, Séverine Maunoir-Regimbal, Emmanuel Flahaut, Jean-Claude Debouzy, et al.. Biological effects of double-walled carbon nanotubes on the innate immune system: An in vitro study on THP-1 human monocytes. Toxicology, 2016, vol. 365, pp. 1-8. 10.1016/j.tox.2016.07.019 . hal-01486943

\section{HAL Id: hal-01486943 \\ https://hal.science/hal-01486943}

Submitted on 10 Mar 2017

HAL is a multi-disciplinary open access archive for the deposit and dissemination of scientific research documents, whether they are published or not. The documents may come from teaching and research institutions in France or abroad, or from public or private research centers.
L'archive ouverte pluridisciplinaire HAL, est destinée au dépôt et à la diffusion de documents scientifiques de niveau recherche, publiés ou non, émanant des établissements d'enseignement et de recherche français ou étrangers, des laboratoires publics ou privés. 


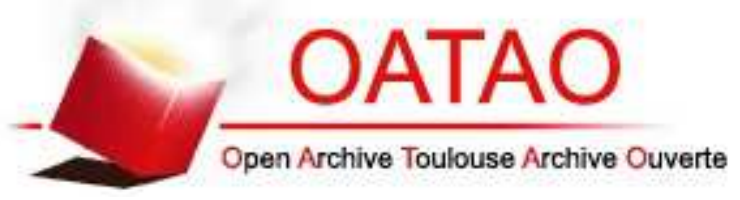

\section{Open Archive TOULOUSE Archive Ouverte (OATAO)}

OATAO is an open access repository that collects the work of Toulouse researchers and makes it freely available over the web where possible.

This is an author-deposited version published in : http://oatao.univ-toulouse.fr/ Eprints ID : 16751

To link to this article : DOI:10.1016/j.tox.2016.07.019

URL : http://dx.doi.org/10.1016/j.tox.2016.07.019

To cite this version : Dekali, Samir and Bachelet, Christine and Maunoir-Regimbal, Séverine and Flahaut, Emmanuel and Debouzy, Jean-Claude and Crouzier, David Biological effects of double-walled carbon nanotubes on the innate immune system: An in vitro study on THP-1 human monocytes. (2016) Toxicology, vol. 365. pp. 1-8. ISSN 0300-483X

Any correspondence concerning this service should be sent to the repository administrator: staff-oatao@ listes-diff.inp-toulouse.fr 


\title{
Biological effects of double-walled carbon nanotubes on the innate immune system: An in vitro study on THP-1 human monocytes
}

\author{
Samir Dekali ${ }^{\mathrm{a}, *}$, Christine Bachelet $^{\mathrm{a}}$, Séverine Maunoir-Regimbal ${ }^{\mathrm{a}}$, Emmanuel Flahaut $^{\mathrm{b}}$, \\ Jean-Claude Debouzy ${ }^{\mathrm{a}}$, David Crouzier ${ }^{\mathrm{a}}$ \\ a Institut de Recherche Biomédicale des Armées (IRBA), Département EBR/Unité des Risques Technologiques Emergents, 1, place du Général Valérie André, \\ BP73, 91223 Brétigny-sur-Orge Cedex, France \\ ${ }^{\mathrm{b}}$ CIRIMAT, Université de Toulouse, CNRS, INPT, UPS, UMR CNRS-UPS-INP No. 5085, Université Toulouse 3 Paul Sabatier, Bât. CIRIMAT, 118, route de Narbonne, \\ 31062 Toulouse Cedex 9, France
}

Keywords:

THP-1 monocytes

Double-walled carbon nanotubes

Inflammation

Innate immunity

LPS
A B S T R A C T

DWCNTs have numerous industrial and biomedical applications and several studies reported that they could act as immunomodulator systems. The immune system is the first line of defence of the human body when exposed to particulate matter. In order to investigate DWCNTs' role on innate immunity, we used THP-1 monocytic cells for the purpose of this study.

We showed that DWCNTs were not cytotoxic until $6 \mathrm{~h}, 24 \mathrm{~h}, 48 \mathrm{~h}$ and $72 \mathrm{~h}$ of incubation with THP-1 monocytic cells (concentrations tested from 10 to $50 \mu \mathrm{g} / \mathrm{mL}$ ). From $6 \mathrm{~h}$ to $72 \mathrm{~h}$ of incubation of THP- 1 cells with DWCNTs, we measured a significant increase of the baseline cell index using $x$ CELLigence ${ }^{\circledR}$ technology showing cell adhesion. After $24 \mathrm{~h}$ of exposure, DWCNTs agglomerates were localized in THP- 1 monocyte cytoplasm and cell adhesion was observed simultaneously with a significant increase in the expression of CD11b and CD14 cell surface proteins. Pro-inflammatory cytokine secretion (IL-1 3 , IL-6, IL8 , TNF- $\alpha$ and IL-10) was also measured in supernatants after $6 \mathrm{~h}$ or $24 \mathrm{~h}$ of exposure to DWCNTs. This proinflammatory response was increased in THP-1 monocytic cells pre-treated with LPS.

Altogether, our data indicate that DWCNTs induce an increased pro-inflammatory response of THP-1 monocytes and seem to modulate cell surface protein expression confirming that DWCNTs could act as stimulators of innate immunity.

\section{Introduction}

Nano-objects can be defined as having at least one dimension less than 100 nanometers ( $\mathrm{nm}$ ) in length. Among nano-objects, nanotubes are defined as having at least two dimensions in the nanoscale (less than $100 \mathrm{~nm}$ ) (ISO, 2008). Carbon nanotubes (CNTs) are cylindrical carbon molecules, which can be divided into two major groups: single-walled carbon nanotubes (SWCNTs), which are made up of a single graphite sheet, wrapped into a cylindrical tube, and multi-walled carbon nanotubes (MWCNTs) which are multiple SWCNTs, concentrically nested. Due to their unique physico-chemical properties such as electrical conductivity, mechanical strength and thermal conductivity, MWCNTs could be or are being used in various industrial sectors such as

\footnotetext{
* Corresponding author.

E-mail address: samir.dekali@gmail.com (S. Dekali).
}

electronics, aerospace or nanomedicine (Baughman et al., 2002; Mundra et al., 2014).

However, their intrinsic physico-chemical properties also raise the question of their effects on human health. Interestingly, a recent study showed that anthropogenic carbon nanotubes are found in the airways of asthmatic Parisian children, indicating a daily environmental exposure to these nano-objects (KolosnjajTabi et al., 2015). The International Agency for Research on Cancer (IARC) recently classified one type of MWCNTs (MWCNT-7) as "possibly carcinogenic to humans" (Group 2B); and SWCNTs and MWCNTs (excluding MWCNT-7) were categorised as not classifiable as to their carcinogenicity to humans (Group 3) (Grosse et al., 2014). Several studies report potentially toxic effects of SWCNTs or MWCNTs to human health but these biological effects are merely being discussed and still not very well understood (Ong et al., 2014; Liu et al., 2013; Miozzi et al., 2016). The immune system is the first line of defence of the human body when exposed to particulate matter like CNTs. Several studies have pointed out the implications of the immune response after exposure to MWCNTs. A recent study 
showed that ICR (The Institute for Cancer Research) mice exposed to MWCNT-7 (single intraperitoneal administration) exhibit sustained stimulating effects on immune and inflammatory responses (Yamaguchi et al., 2012). Other authors showed that MWCNTs intratracheal instillation might induce allergic responses in mice through B cell activation by Th2-type cytokines (IL-4, IL-5 and IL-10), and IgE production (Park et al., 2009). Moreover, Laverny and colleagues showed, using peripheral blood mononuclear cells (PBMCs), that exposure to MWCNTs can promote or suppress immune response depending on the cell's origin: from healthy subjects and from patients with allergy against house dust mites, respectively (Laverny et al., 2013). Interestingly, it has recently been shown that MWCNT exposure increases adhesion of THP-1 monocytes to endothelial cells in an in vitro model of the alveolo-capillary barrier (constituted of A549 epithelial and HUVECs endothelial cell lines) simultaneously with oxidative stress, indicating an increased expression of THP-1 monocytic cell surface adhesion proteins (Cao et al., 2015). It has been shown that monocytes in response to environmental stimuli can differentiate into inflammatory or anti-inflammatory subsets (Yang et al., 2014). Pondman et al. showed that complement opsonisation of CNTs significantly increase their internalization with concomitant down-regulation of pro-inflammatory cytokines and up-regulation of anti-inflammatory cytokines in both U937 cells and human monocytes (Pondman et al., 2014). It was notably reported that CNTs injected into mice induced inflammation and activation of innate cells such as monocytes/macrophages, resulting in proinflammatory cytokine secretion, which in turn stimulates Th cells (Grecco et al., 2011; Yamaguchi et al., 2012). Hamilton and his colleagues investigated how MWCNTs' physico-chemical characteristics may influence bioactivity on THP-1 macrophages. They found that increased MWCNT length or diameter raised inflammasome activation and pro-inflammatory response in these cells, similarly to alveolar macrophages isolated from C57BL/6 mice (Hamilton et al., 2013).

In the present study, we tested CNTs (approximately 80\% double-walled CNTs, $20 \%$ SWCNTs and a few triple-walled CNTs) to explore the effects on THP-1 monocyte phenotype, CNT cellular internalization and pro-inflammatory response, using flow cytometry, transmission electron microscopy (TEM) and multiplex ELISA. Our aim was to determine the role of CNTs on monocyte function. We showed, after $24 \mathrm{~h}$ of exposure, that CNTs were not cytotoxic but were internalized by THP- 1 monocytic cells. THP-1 cells became adherent and significant increases in pro-inflammatory cytokines and chemokines were measured in supernatants (IL-1 $\beta$, IL-6, IL-8, TNF- $\alpha$ and IL-10) compared to controls. Moreover, we measured an increased expression of CD11b and CD14 cell surface proteins compared to controls. CD11b is the $\alpha$ subunit of the integrin cell surface receptor complement receptor 3 and functions in a heterodimer with CD18 to allow recognition and phagocytosis of iC3b opsonized particles (Pahl et al., 1993). CD11b is selectively expressed on the surface of mature monocytes, macrophages, granulocytes and natural killer cells. CD14, on the other hand, functions in concert with LPS binding protein and TLR4 in the detection and binding of lipopolysaccharide (Methe et al., 2005).

Because DWCNTs are at the interface between SWCNTs and MWCNTs with a larger number of walls, we believe that these results can be extrapolated to all kind of CNTs.

\section{Methods}

\subsection{Cell culture}

THP-1 human monocytic cell line was obtained from the European Collection of Cell Cultures (ECACC, Reference 88081201), and grown in RPMI 1640 medium containing Glutamax ${ }^{\mathrm{TM}}$ (Life Technologies, Reference 61870 ) supplemented with $10 \%$ (v/v) heatinactivated fetal bovine serum (FBS; Lonza, Reference DE14-801) and antibiotics $100 \mathrm{U} / \mathrm{mL}$ penicillin and $100 \mu \mathrm{g} / \mathrm{mL}$ streptomycin (Life Technologies, Reference15140). In order to avoid any cellular stress, cells were maintained in exponential growth between 2 and $9 \times 10^{5}$ cells $/ \mathrm{mL}$ in a humidified atmosphere at $37^{\circ} \mathrm{C}$ and $5 \% \mathrm{CO}_{2}$.

\subsection{DWCNTs synthesis, preparation and characterization}

DWCNTs were produced by catalytic chemical vapour decomposition (CCVD) of $\mathrm{CH}_{4}$ over $\mathrm{MgC1}_{\mathrm{x}} \mathrm{Co}_{\mathrm{x}} \mathrm{O}$ solid solution containing a small addition of Molybdenum (Flahaut et al., 2003). After CCVD, the catalyst and support were removed by treatment of the sample with a concentrated aqueous hydrochloric acid solution. Highresolution transmission electron microscopy (TEM) showed that a typical sample consists of 77\% DWCNTs, $18 \%$ SWCNTs and 5\% triplewalled CNTs. Diameter distribution of DWCNTs ranged from 0.5 to $2.5 \mathrm{~nm}$ for inner tubes (median inner diameter $=2.0 \mathrm{~nm}$ ) and from 1.2 to $3.2 \mathrm{~nm}$ for outer tubes (median outer diameter $=1.3 \mathrm{~nm}$ ). The length of individual DWCNTs usually ranges between 1 and $10 \mu \mathrm{m}$, although bundles may be much longer (up to $100 \mu \mathrm{m}$, at least). Due to the synthesis and catalyst-elimination process, the walls of the DWCNTs are not expected to be functionalized (particularly by oxygen-containing functional groups). Brunauer Emmet Teller (BET) specific surface area was $985 \mathrm{~m}^{2} / \mathrm{g}$.

DWCNTs were sterilized and then dispersed in PBS containing $25 \%(\mathrm{v} / \mathrm{v})$ FBS at a concentration of $5 \mathrm{mg} / \mathrm{mL}$ by vortexing for $30 \mathrm{~s}$ and sonicating for $5 \mathrm{~min}$ in an ultrasonic bath (Advantage Lab, Catalogue number $\mathrm{Al} \mathrm{04-02)}$ at room temperature. This procedure was repeated five times. A "sham stock solution" of sterile PBS containing 25\% (v/v) FBS was prepared and sonicated in parallel for use as control. These stock solutions were kept at $4{ }^{\circ} \mathrm{C}$. Before cell exposure, the DWCNTs' stock solution was firstly vortexed for $30 \mathrm{~s}$ and then sonicated for $5 \mathrm{~min}$ in an ultrasonic bath. Suspensions were then diluted in the complete cell culture medium to the required concentration.

DWCNTs were suspended at a concentration of $200 \mu \mathrm{g} / \mathrm{mL}$ in the complete culture medium and then particle size distribution was measured using laser diffraction granulometry (Horiba, Partica LA-950 V2).

\subsection{Trypan blue exclusion assay}

THP-1 cells were seeded in 12-well plates and immediately incubated with DWCNTs at different concentrations $(0,10,25$ and $50 \mu \mathrm{g} / \mathrm{mL}$ ) in RPMI 1640 medium supplemented with 10\% (v/v) FCS for $6 \mathrm{~h}, 24 \mathrm{~h}, 48 \mathrm{~h}$ or $72 \mathrm{~h}$ at $37^{\circ} \mathrm{C}$. Then, cell suspensions were diluted to half with $100 \mu \mathrm{L}$ of a mix containing RPMI 1640 medium supplemented with $10 \%(\mathrm{v} / \mathrm{v})$ FCS (50\% v/v) and Trypan blue (Life Technologies, Catalogue number 15250-061) (50\% v/v). After $1 \mathrm{~min}$, viable and dead cells were counted under a light microscope (Leitz Laborlux K).

\subsection{LIVE/DEAD ${ }^{\circledR}$ cytotoxicity assay}

Cell suspensions were exposed to DWCNTs at different concentrations $(0,10,25$ and $50 \mu \mathrm{g} / \mathrm{mL})$ in 24-well culture plates for $48 \mathrm{~h}$ or $72 \mathrm{~h}$. Cytotoxicity was then assessed using the LIVE/ DEAD $^{\circledR}$ viability/cytotoxicity kit for mammalian cells (Life Technologies, Reference L-3224) according to the manufacturer's instructions and analysed using a flow cytometer (Becton Dickinson Biosciences, LSRII). This assay allows simultaneous determination of live and dead cells using two probes: on the one hand, non fluorescent cell-permeant calcein AM is cleaved by cytoplasmic esterases producing intensely green fluorescent calcein 
well retained within live cells, on the other hand, ethidium homodimer (EthD-1) enters cells with damaged membranes and, upon binding to nucleic acids, produces a bright red fluorescence. EthD-1 is excluded by the intact plasma membrane of live cells. CountBright ${ }^{\mathrm{TM}}$ Absolute Counting Beads (Life Technologies, Reference C36950) were used to quantify cell populations, and were added prior to data acquisition on a BDLSR II ${ }^{\mathrm{TM}}$ flow cytometer with BD FACSDiva ${ }^{\circledR}$ software. Fluorescence emission of cells was analyzed using $488 \mathrm{~nm}$ excitation wavelength. For each sample, $3 \times 10^{3}$ beads events were collected to ensure statistically significant determination of sample volumes, and mean fluorescence of about $5.5 \times 10^{4}$ cells was determined. A gating with a combination of parameters separated all events. Counting Beads were brightly fluorescent at the two emission wavelengths $(\lambda$ excitation $=488 \mathrm{~nm} ; \lambda$ emission for calcein $=530 \mathrm{~nm} /$ bandpass $30 \mathrm{~nm}$ and $\lambda$ emission for ethidium homodimer $-1=610 \mathrm{~nm} /$ $20 \mathrm{~nm}$ bandpass) while DWCNTs were not. No interference between bead and DWCNT fluorescence was recorded (data not shown). Data analysis was realized using FCS Express ${ }^{\circledR}$ Software (De Novo Software).

\section{5. xCELLigence real-time cell analysis (RTCA): cell adhesion assay}

Real time monitoring of THP-1 living cells was performed using the $x$ CELLigence RTCA DP instrument (ACEA Biosciences) which was placed in a humidified incubator at $37^{\circ} \mathrm{C}$ and $5 \% \mathrm{CO}_{2}$.

Cell adhesion experiments were carried out using 16-well plates (ACEA Biosciences, Reference 00300600880). Initially, $100 \mu \mathrm{L}$ of culture medium was added to each well and a background measurement step was performed as a background signal generated by cell-free medium. To initiate the experiment, THP- 1 cells were counted and seeded at concentrations of $3 \times 10^{4}$ viable cells/well and directly exposed to DWCNTs (10 and $50 \mu \mathrm{g} / \mathrm{mL}$ ) or $15 \mathrm{ng} / \mathrm{mL}$ phorbol 12-myristate 13 acetate (PMA; Sigma-Aldrich, Reference P8139). Control cells were only incubated with cell culture medium. Each condition was performed in quadruplicate with a programmed signal detection schedule once every minute during $72 \mathrm{~h}$ of incubation.

\subsection{Surface antigen expression}

After $48 \mathrm{~h}$ or $72 \mathrm{~h}$ of incubation of DWCNTs with $7.5 \times 10^{5}$ THP- 1 monocytes, cells were centrifuged, washed with PBS and incubated with $200 \mu \mathrm{L}$ of a mix solution of diluted FITC-conjugated antihuman CD11b (Beckman Coulter, Reference IMO530) and RD1conjugated anti-human MY4 (CD14, Beckman Coulter, Reference 6603262) monoclonal antibodies (1:10 and 1:40 dilutions respectively) in PBS for $40 \mathrm{~min}$ at $4{ }^{\circ} \mathrm{C}$. Cells were then washed twice with $2 \mathrm{~mL}$ of PBS. Cell pellet was then resuspended with $0.5 \mathrm{~mL}$ of PBS containing $1 \mu \mathrm{g} / \mathrm{mL}$ Hoechst 33258 (Invitrogen, Reference H3569) and kept on ice protected from light until flow cytometry analysis. Individual compensation settings were performed using antibody-capture beads (Beckton Dickinson Biosciences, CompBeads). Appropriate isotypic controls (Beckman Coulter; IgG1-FITC, Reference A07795; and MsIgG2B-RD1, Reference 6603038) were used to determine non-specific staining of monoclonal antibodies, based on the fluorescence minus one (FMO) controls. $5 \times 10^{4}$ events were recorded. Gating on the Forward Scatter (FSC) area and FSC width signals performed doublets discrimination. Staining with Hoechst 33258 and UV excitation of the dye gated out dead cells. Mean fluorescence intensity (MFI) for each labelling was quantified and the relative fluorescence intensity (RFI) was calculated as follows:

$\mathrm{RFI}=\mathrm{MFI} / \mathrm{MFI}$ of corresponding FMO control

\subsection{Inflammatory cytokine release detection}

THP-1 monocytes were incubated with different concentrations of DWCNTs $(0,10,25$ and $50 \mu \mathrm{g} / \mathrm{mL})$ in 24-well culture plates for $6 \mathrm{~h}$ or $24 \mathrm{~h}$. Pre-treatments with $100 \mathrm{ng} / \mathrm{mL}$ LPS were also performed to investigate THP-1 pro-inflammatory response of conditioned cells. After these incubations, cells were centrifuged at $2000 \times g$ for $10 \mathrm{~min}$. Then, supernatants were collected and an additional centrifugation at $2000 \times g$ for $10 \mathrm{~min}$ was realized before storage at $-80^{\circ} \mathrm{C}$ until cytokine release analysis. Quantification of IL-1 $\beta$, IL-6, IL-8, IL-10, IL-12, and TNF- $\alpha$ was performed simultaneously in supernatants $(50 \mu \mathrm{L})$ using the Cytometric Bead Array kit (CBA; Beckton Dickinson Biosciences) according to the manufacturer's instructions. Samples were acquired on a LSR II ${ }^{\mathrm{TM}}$ flow cytometer and concentrations of each cytokine were determined in $\mathrm{pg} / \mathrm{mL}$ on the basis of standard curves and regression analysis. Limits of detection for each protein using the CBA kit were: IL-1 $\beta(7.2 \mathrm{pg} / \mathrm{mL}), \mathrm{IL}-6(2.5 \mathrm{pg} / \mathrm{mL}), \mathrm{IL}-8(3.6 \mathrm{pg} /$ $\mathrm{mL})$, IL-10 (3.3 pg/mL), IL-12 $(1.9 \mathrm{pg} / \mathrm{mL})$ and TNF- $\alpha(3.7 \mathrm{pg} / \mathrm{mL})$.

\subsection{Electron microscopy}

Cellular suspensions were fixed in a solution of $4 \%(\mathrm{v} / \mathrm{v})$ glutaraldehyde in $0.1 \mathrm{M}$ cacodylate buffer at $\mathrm{pH}$ 7.4. Cells were post-fixed in a $1 \%(\mathrm{v} / \mathrm{v})$ osmium tetroxide solution during $2 \mathrm{~h}$ at room temperature. THP-1 monocytes were then mixed in a liquid low melting point gelatine solution and quickly brought back to room temperature. Samples of solid gelatine were cut, dehydrated and embedded in Spurr resin (Sigma-Aldrich, Reference EM0300). Semi-thin sections of $1 \mu \mathrm{m}$ stained with Toluidine blue were used for histological analysis (data not shown). Ultrathin sections stained with uranyl acetate and post stained with lead citrate were observed on a JEOL 1010 transmission electron microscope. Photographs were taken with a Gatan ES 500 camera.

\subsection{Statistical analysis}

Data are represented as mean of three independent experiments \pm standard deviation (SD). Data were analysed by one-way analysis of variance (ANOVA) followed by Dunnett's $t$-test to compare the different groups treated to the control ( $\alpha$ risk $=0.05$ ). To examine differences between pairs of groups, Student's $t$-tests $(\alpha$ risk $=0.05)$ were used.

\section{Results}

3.1. Characterization of size distribution of DWCNTs in the relevant biological media

To analyze size distribution of DWCNT agglomerates in cell culture media, we used laser diffraction. Size analysis revealed micronic agglomerates with sizes comprised between 3.9 and $44.9 \mu \mathrm{m}$ (Fig. 1). The measured median diameter is $6.9 \pm 1.7 \mu \mathrm{m}$.

\subsection{DWCNTs do not induce cytotoxicity on THP-1 monocytic cells}

To measure cytotoxicity of DWCNTs on THP- 1 monocytic cells avoiding interferences with the assay, we performed, on the one hand, Trypan blue assay. After $6 \mathrm{~h}, 24 \mathrm{~h}, 48 \mathrm{~h}$ or $72 \mathrm{~h}$ of incubation, DWCNTs did not induce significant cytotoxicity on THP-1 monocytes (Fig. 2).

On the other hand, we used the LIVE/DEAD ${ }^{\circledR}$ viability/ cytotoxicity assay kit. No significant decrease in the cell viability was observed after $48 \mathrm{~h}$ or $72 \mathrm{~h}$ of incubation with THP-1 cells (Fig. S1). 


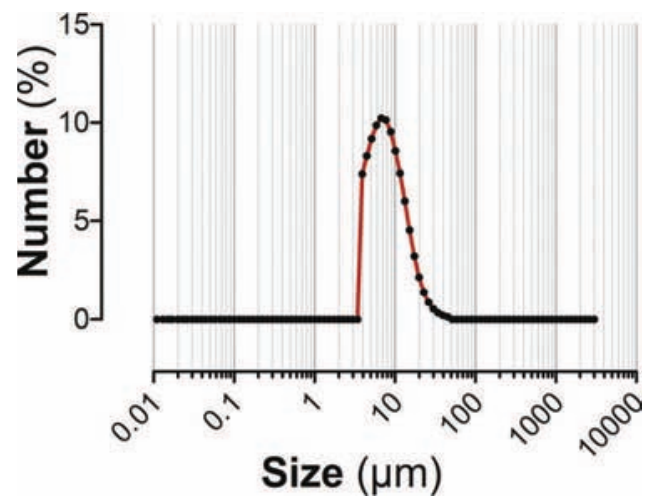

Fig. 1. Size distribution of DWCNTs in the culture medium. Size analysis was performed using laser diffraction. DWCNTs were suspended in RPMI 1640 cell culture medium supplemented with $10 \%(\mathrm{v} / \mathrm{v})$ FBS. The curve represents DWCNTs size distribution of one representative experiment.

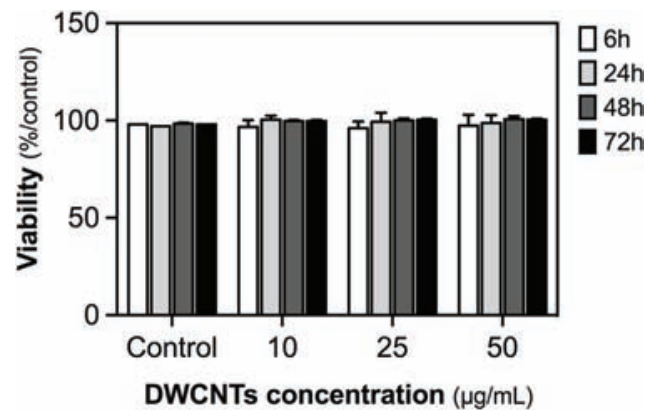

Fig. 2. Cytotoxicity of DWCNTs on THP- 1 cells. THP-1 cells were incubated for $6 \mathrm{~h}$, $24 \mathrm{~h}, 48 \mathrm{~h}$ or $72 \mathrm{~h}$ to DWCNTs. Cell viability was measured using Trypan blue. Data represent the mean (SD) of three independent experiments.

\subsection{DWCNTs induce cell adhesion}

To determine if DWCNTs have an effect on cell adhesion, we used xCELLigence ${ }^{\circledR}$ technology. Real time monitoring of living cells using xCELLigence ${ }^{\circledR}$ technology is a useful high throughput screening method allowing to measure cell adhesion. The more cells are attached to the electrodes of the E-plate, the larger the increase in electrode impedance.

We showed that baseline cell index was immediately, significantly increased after incubation with $15 \mathrm{ng} / \mathrm{mL}$ PMA

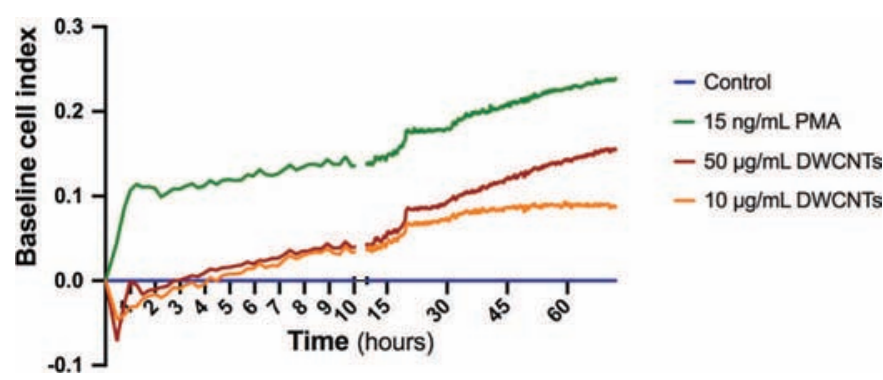

Fig. 3. Real time cell monitoring of THP-1 monocytes exposed to DWCNTs. Curves represent the baseline cell index across time. Control cells (blue curve, baseline) are only incubated in cell culture medium. THP-1 monocytes were incubated with $15 \mathrm{ng} / \mathrm{mL}$ phorbol 12-myristate 13 -acetate (PMA; red curve), 10 or $50 \mu \mathrm{g} / \mathrm{mL}$ DWCNTs (orange and red curves, respectively). Data represent one representative experiment of quadruplicates during $72 \mathrm{~h}$ (For interpretation of the references to colour in this figure legend, the reader is referred to the web version of this article.) (positive control) indicating that THP-1 monocytes became adherents (Fig. 3). After $6 \mathrm{~h}$ of exposure to 10 or $50 \mu \mathrm{g} / \mathrm{mL}$ DWCNTs, baseline cell indexes were significantly increased. From $20 \mathrm{~h}$ to $72 \mathrm{~h}$, after $50 \mu \mathrm{g} / \mathrm{mL}$ DWCNT incubation, baseline cell indexes were significantly more increased than $10 \mu \mathrm{g} / \mathrm{mL}$ DWCNTs. Consequently, increase in baseline cell index seems to be concentration-dependent.

To ensure that increases in baseline cell indexes were not due to sedimentation of DWCNT agglomerates, we used control wells containing only DWCNTs. No significant increase in the baseline cell index was measured (data not shown).

\subsection{DWCNTS are internalized by THP-1 monocytic cells and induce $C D 11 b$ and $C D 14$ expression}

In order to determine if THP-1 monocytes are able to internalize DWCNTs, we performed observations by TEM. After $24 \mathrm{~h}$ of incubation of $10 \mu \mathrm{g} / \mathrm{mL}$ DWCNTs, THP-1 cells became adherent and we observed nanoparticle agglomerates in the cytoplasm (Fig. 4A and B). These agglomerates look like carbon encapsulated Co nanoparticles described to be present in the raw material. This may be an indirect evidence of the presence of associated CNTs. Size of internalized agglomerates was in the micron range. No DWCNTs were observed in cell nuclei nor in the nucleolus.

Because we observed DWCNT internalization and cell adhesion, we investigated if expression of differentiation surface markers was induced. Once differentiated, THP-1 cells express CD11b and CD14 on their plasma membrane (Moeenrezakhanlou et al., 2008). CD11b expression was significantly increased after $48 \mathrm{~h}$ and $72 \mathrm{~h}$ DWCNT exposure up to approximately $36 \%$ and $60 \%$ respectively for each tested concentration, compared to corresponding controls (Fig. 4C). Significant amounts of CD14 were also measured after $48 \mathrm{~h}$ and $72 \mathrm{~h}$ DWCNT exposure up to approximately $22 \%$ and $24 \%$ respectively for each tested concentration compared to corresponding controls (Fig. 4D).

\subsection{DWCNTs induce pro-inflammatory cytokine and chemokine release by THP-1 monocytes}

To explore the DWCNTs' pro-inflammatory effects we measured cytokine and chemokine secretion (IL-1 $\beta$, IL-6, IL-8, TNF- $\alpha$, IL-10 and IL-12) in THP-1 cell supernatants, after $6 \mathrm{~h}$ or $24 \mathrm{~h}$ of exposure. To determine if differential effects were observed on stimulated THP-1 monocytes, the same experiments were performed on LPS pre-treated cells.

\section{Effects of DWCNTs on THP-1 cells after $6 \mathrm{~h}$ of incubation}

Significant amounts of IL- $1 \beta$ and IL- 8 were detected after incubation with 25 and $50 \mu \mathrm{g} / \mathrm{mL}$ DWCNTs compared to controls (Fig. 5A and C), while significant releases of IL-6, TNF- $\alpha$ and IL-10 were only measured in response to $50 \mu \mathrm{g} / \mathrm{mL}$ DWCNT exposure (Fig. 5B,D,E). Significant secretion of IL-12 was not detected in any of the cell supernatants in our conditions (Fig. 5F).

In case of LPS pre-treated THP-1 cells, significant amounts of IL$1 \beta$ were detected at 25 and $50 \mu \mathrm{g} / \mathrm{mL}$ (Fig. $5 \mathrm{~A}$ ), and significant releases of TNF- $\alpha$ and IL-10 were measured in response to $50 \mu \mathrm{g} /$ $\mathrm{mL}$ DWCNT incubation (Fig. 5D and E) compared to controls.

Statistical comparisons revealed significant differences between cells with or without LPS pre-treatment for IL-6 $(10 \mu \mathrm{g} / \mathrm{mL}$; Fig. 3B), IL-8 (0, 10 and $25 \mu \mathrm{g} / \mathrm{mL}$; Fig. 5C) and IL-10 (25 and $50 \mu \mathrm{g} /$ $\mathrm{mL}$; Fig. 5E).

\section{Effects of DWCNTS on THP-1 cells after $24 \mathrm{~h}$ of incubation}

Significant increase in IL-1 $\beta$ secretion was measured after incubation with 25 and $50 \mu \mathrm{g} / \mathrm{mL}$ DWCNTs compared to controls (Fig. 5A). Significant secretions of IL-6, IL-8, TNF- $\alpha$ and IL-10 were 

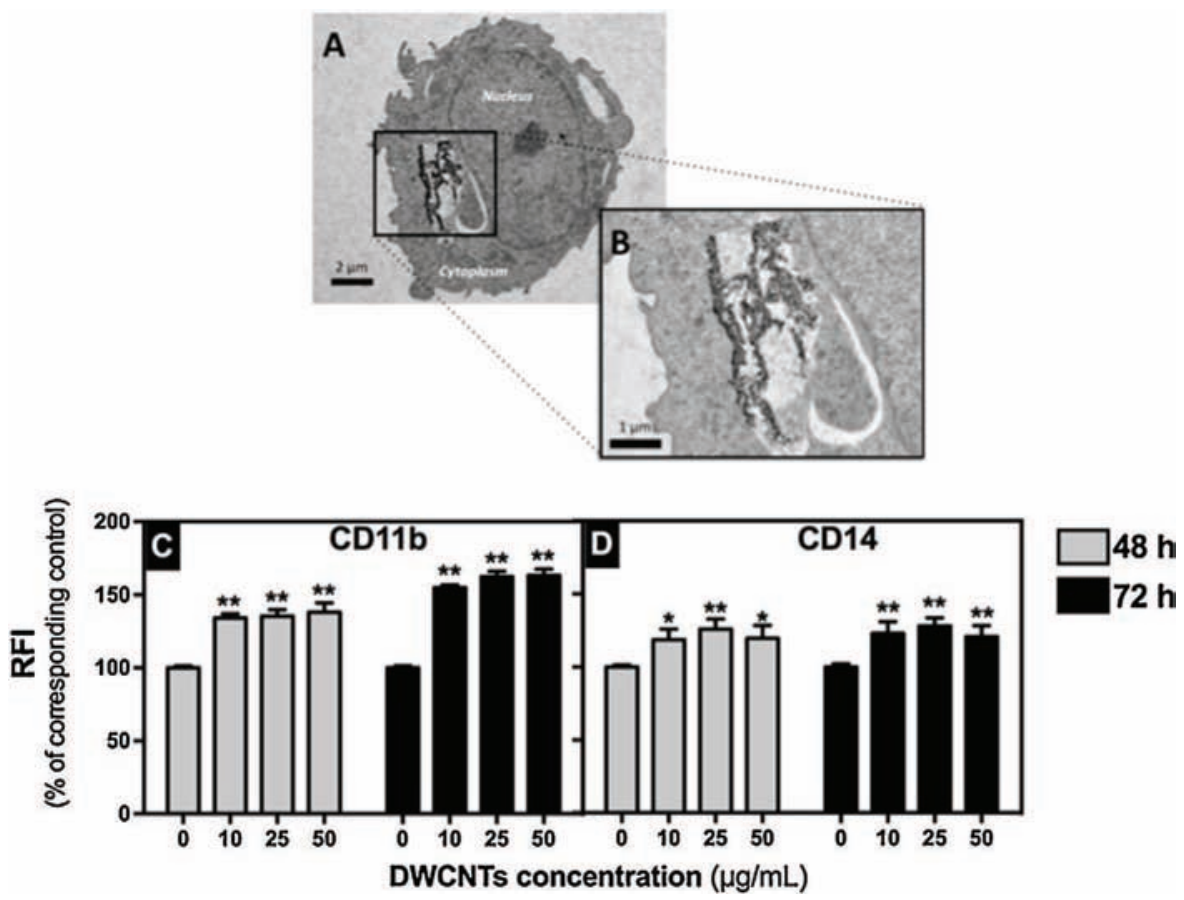

Fig. 4. DWCNTs internalization and differentiation surface markers expression by THP- 1 cells. After exposure to $10 \mu \mathrm{g} / \mathrm{mL}$ DWCNTs for $24 \mathrm{~h}$, THP- 1 cells were observed by transmission electron microscopy (A; scale bar $2 \mu \mathrm{m}$ ). DWCNTs were detected in the cytoplasm of these monocytes (B; scale bar $1 \mu \mathrm{m}$ ). After exposure to $10 \mu \mathrm{g} / \mathrm{mL}$ DWCNTs for $48 \mathrm{~h}$ ( $C$ and D, grey bars) or $72 \mathrm{~h}$ (C and D black bars), CD11b (C) and CD14 (D) differentiation surface marker expression by THP-1 cells was determined by flow cytometry. Mean fluorescence intensity for each labeling was quantified and expressed as the relative fluorescence intensity (RFI) reported in percentage of the corresponding control. Data represent the mean (SD) of three independent experiments. One-way ANOVA and Dunett's post-test (comparisons vs. control cells not exposed to DWCNTs) were performed $\left({ }^{*} p<0.1 ;{ }^{* *} p<0.01\right)$.
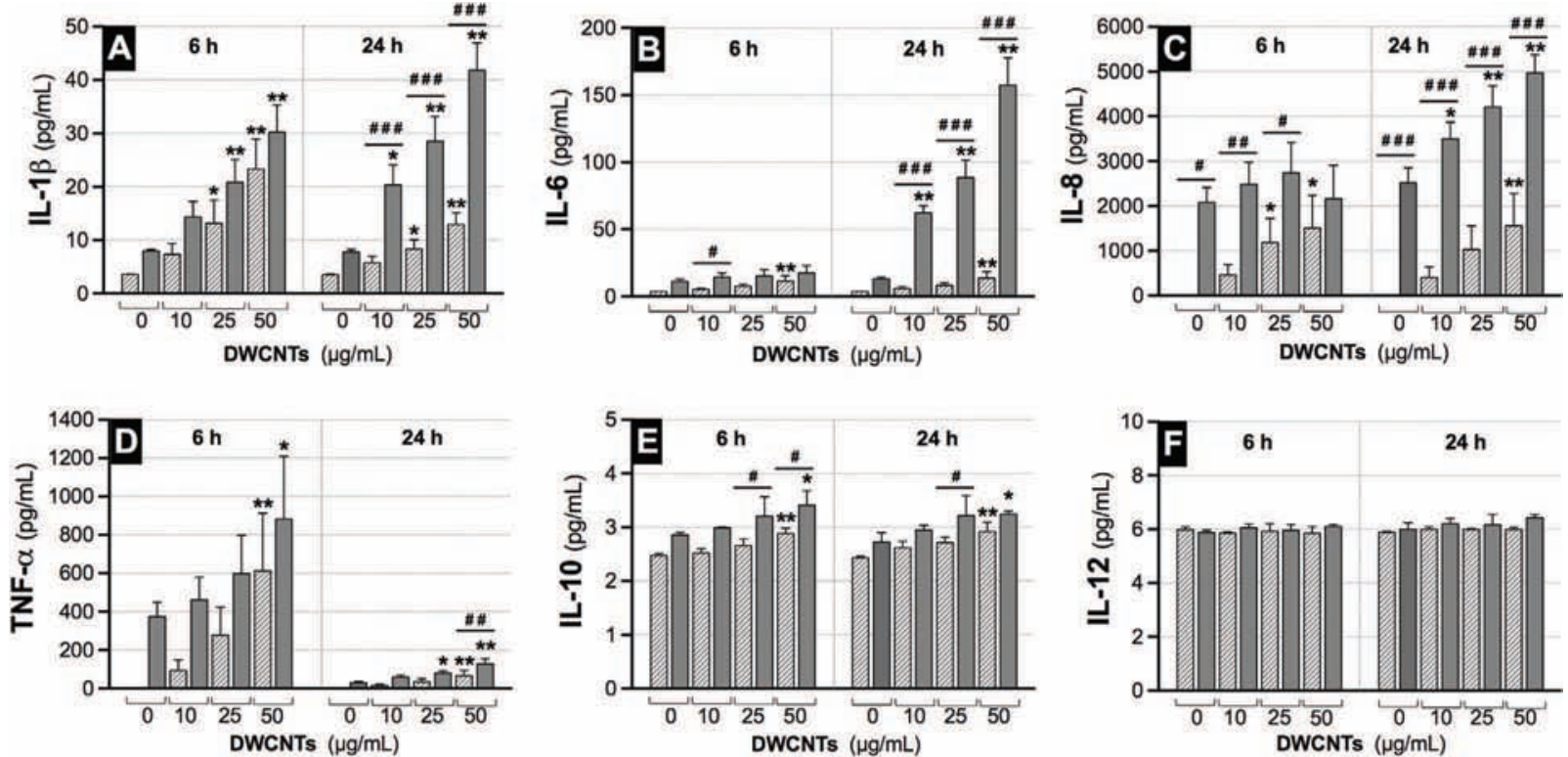

\section{Without LPS $\square$ LPS pre-treatment}

Fig. 5. Pro-inflammatory potential of DWCNTs on THP-1 cells. Cells were exposed for h or $24 \mathrm{~h}$ to $0,10,25,50 \mathrm{mg} / \mathrm{mL}$ DWCNTs without or with $100 \mathrm{ng} / \mathrm{mL}$ LPS pre-treatment (hatched or grey bars respectively). IL-1 $\beta$, IL-6, IL-8, TNF- $\alpha$, IL-10 and IL-12 were then measured by ELISA multiplex in cell supernatants (A, B, C, D, E and F respectively). Data represent the mean (SD) of three independent experiments. One-way ANOVA and Dunett's post-test were performed to compare each DWCNTs exposed cells to corresponding controls $\left({ }^{*} p<0.1 ;{ }^{* *} p<0.01 ;{ }^{* * *} p<0.001\right)$. One-way ANOVA and Tukey's post-test were also performed to compare for each DWCNTs concentration not LPS pre-treated cells vs. pre-treated cells $(\# p<0.1 ; \# \# p<0.01$; \# \# \#p<0.001). 
detected in response to the highest dose of DWCNTs $(50 \mu \mathrm{g} / \mathrm{mL}$; Fig. 5B-D).

For LPS pre-treated THP-1 monocytic cells, significant amounts of IL-1 $\beta$, IL-6 and IL-8 were secreted at 10,25 and $50 \mu \mathrm{g} / \mathrm{mL}$ compared to controls (Fig. $5 \mathrm{~A}-\mathrm{C}$ ). Significant increases in TNF- $\alpha$ and IL-10 were respectively detected at 25 and $50 \mu \mathrm{g} / \mathrm{mL}$ DWCNTs (Fig. 5D), and $50 \mu \mathrm{g} / \mathrm{mL}$ DWCNTs (Fig. 5E).

Statistical comparisons revealed significant differences between cells with or without LPS pre-treatment for IL-1 $\beta(10,25$, $50 \mu \mathrm{g} / \mathrm{mL}$; Fig. 3A), IL-6 (10, 25, $50 \mu \mathrm{g} / \mathrm{mL}$; Fig. 3B), IL-8 (0, 10, 25 and $50 \mu \mathrm{g} / \mathrm{mL}$; Fig. $5 \mathrm{C})$ and IL-10 (25 $\mu \mathrm{g} / \mathrm{mL}$; Fig. 5E).

\section{Discussion}

The objective of this study was to assess involvement of innate immunity and inflammatory response after DWCNT exposure. For this purpose, monocytic THP- 1 cells were incubated $6 \mathrm{~h}, 24 \mathrm{~h}, 48 \mathrm{~h}$ or $72 \mathrm{~h}$ with DWCNTs. We have clearly shown that secretion of proinflammatory cytokines (IL-1 $\beta$, IL-6, IL-8, TNF- $\alpha$ and IL-10) after exposure to DWCNTs was concomitant to cellular adhesion and to CD11b/CD14 increased expression.

The state of agglomeration of DWCNTs was characterized in exposure media containing $10 \%$ FCS. Given that the primary length of DWCNTs usually ranges between 1 and $10 \mu \mathrm{m}$, we found that DWCNTs were agglomerated in the cell culture medium with a size distribution between 3.9 and $44.9 \mu \mathrm{m}$. Interestingly, Sauer et al. have recently shown that bovine serum albumin (BSA) containing media induced stronger agglomeration than porcine lung surfactant (Sauer et al., 2015). Consequently, we hypothesized that the agglomeration could be due to the large amount of FCS (containing BSA) in the cell culture medium used in this study.

We found that DWCNTs did not induce cytotoxicity after $6 \mathrm{~h}$, $24 \mathrm{~h}, 48 \mathrm{~h}$ and $72 \mathrm{~h}$ of incubation with THP-1 monocytes. In literature, THP- 1 cells are mainly used differentiated in "macrophage-like" cells after incubation with inducers such as phorbol 12-myristate 13-acetate (PMA) or 12-O-tetrade-canoylphorbol-13acetate (TPA) (Tsuchiya et al., 1982; Lanone et al., 2009). Only a few studies were focused on DWCNT toxicity on monocytic cells. Recently, Pescatori and colleagues incubated a series of MWCNTs differing in terms of both functional groups and diameter with THP-1 undifferentiated cells (Pescatori et al., 2013). To detect cells undergoing apoptosis and necrosis they analysed annexin-V FITC and propidium iodide staining by flow cytometry. Their results were consistent with our findings, as they did not report cytotoxicity until $100 \mu \mathrm{g} / \mathrm{mL}$ after $24 \mathrm{~h}$ of exposure. Laverny and colleagues also published results consistent with our study, as they did not report cell viability decrease after $48 \mathrm{~h}$ of incubation of human peripheral blood mononuclear cells (PBMC) with MWCNTs (Laverny et al., 2013). However, Haniu and colleagues found cytotoxicity after $24 \mathrm{~h}$ of incubation of undifferentiated THP- 1 cells to 10 or $100 \mu \mathrm{g} / \mathrm{mL}$ MWCNTs (Haniu et al., 2011). This result could be due to the smallest length of MWCNTs (size distribution between 7 and $10 \mu \mathrm{m}$ ). Interestingly, other authors exposed DHD/ $\mathrm{K} 12 / \mathrm{Trb}$ rat cells during $6 \mathrm{~h}$ and $24 \mathrm{~h}$ to the same batch of DWCNTs used in our study and they showed a significant reduction in cell viability (Fiorito et al., 2014). We hypothesized that these rat colon adenocarcinoma cells are more sensitive to DWCNTs than THP-1 monocytic cells.

As innate immunity adherence to endothelia or to the extracellular matrix is a prerequisite for extravasation of monocytes into injured tissues; we have investigated the ability of DWCNTs to induce monocytic adhesion. Recently, Cao et al. found that exposure of HUVECs to MWCNTs significantly increased oxidative stress and THP-1 monocyte adhesion, while another study did not reveal any cytotoxicity of CNTs on the same cell line (Cao et al., 2015; Flahaut et al., 2006). Using xCELLigence ${ }^{\circledR}$ technology, we found that direct incubation with DWCNTs, THP-1 became adherent to E-plates indicating a direct role on innate immunity. This result is consistent with the only study (to our knowledge) showing that CNTs stimulate adhesion of THP-1 monocytes (De Nicola et al., 2013). However, contrary to our study they found that monocytes were not able to internalize CNTs. This could be attributed to different physico-chemical properties between the CNTs used.

In addition to DWCNT agglomerate phagocytosis, we also showed maturation of THP-1 monocytes with increased CD11b and CD14 expression. Normally, CD14 is downregulated during monocyte differentiation in macrophages (Daigneault et al., 2010; Steinbach and Thiele, 1994). Consequently, we suppose that cells obtained after DWCNT incubation are not fully differentiated macrophages. However, we did not find any other study in the literature investigating effects of DWCNT exposure on CD14 expression by human monocytes. Some authors have recently shown that CD14 and CD11b were up-regulated after MWCNT incubation with RAW264.7 macrophages while it down-regulated a complex of toll-like receptor 4 and myeloid differentiation factor 2 (TLR4/MD2) (Meng et al., 2015). Thus, they hypothesized that upregulation of CD14 was related to TLR4 endocytosis and that significant increases of CD11b acting as pattern recognition receptor is linked to the MWCNT phagocytosis process. Another computational study also suggested that CNTs might also be recognized as pathogens by toll-like receptors (Turabekova et al., 2014). Consequently, on the one hand, increased CD14 expression could also be associated to TLR4 endocytosis and/or recognition of DWCNTs by toll-like receptors, but further experiments need to be carried out to confirm this mechanism. On the other hand, phagocytosis has been described as the main mechanism of internalization pathway for CNT agglomerates, bundles, clusters or single dispersed nanotubes $1 \mu \mathrm{m}$ or more in length, while endocytosis or diffusion were attributed to smallest objects (Raffa et al., 2010). Thus, increased CD11b expression is very likely related to the observed phagocytosis of CNT aggregates by THP-1 monocytes. As Elgrabli et al. have recently shown that oxidative stress is implicated in MWCNT degradation by THP-1 macrophagelike cells, it would be interesting to perform additional experiments in order to investigate if this pathway is also involved after THP-1 monocytic cells exposure (Elgrabli et al., 2015).

Yamaguchi and colleagues demonstrated that MWCNTs induced sustained stimulating effects on immune and inflammatory responses after intraperitoneal administration in ICR mice with increased numbers of leukocytes, monocytes and granulocytes in peripheral blood (Yamaguchi et al., 2012). Consequently, it was relevant to investigate the pro-inflammatory effects of DWCNTs on monocytes and we showed a strong pro-inflammatory response after $6 \mathrm{~h}$ or $24 \mathrm{~h}$ of incubation. Concomitantly with cell adhesion and DWCNT phagocytosis, a significant release of IL-1 $\beta$ was measured. This result corroborates the study of Meunier and colleagues demonstrating that the same batch of DWCNTs induced IL-1 $\beta$ release by primary human monocytes requiring potassium efflux and phagocytosis (Meunier et al., 2012). The strong increase in IL- $1 \beta$ could be in a great part due to the fact that these DWCNTs are not surface functionalized. It was shown in vitro, as well as in vivo, that CNT chemical surface functionalization induced significant decreases of IL-1 $\beta$ secretion and recruitment of neutrophils and monocytes (Yang et al., 2013). Interestingly, Kanno et al. recently investigated role Rho kinases (ROCK1, and 2) known to be involved in many cellular functions such as adhesion, regulation of cytoskeleton, and phagocytosis (Kanno et al., 2015). They demonstrate ROCKs involvement in inflammatory response after THP-1 differentiated macrophages exposure to MWCNTs. As we observed adhesion, phagocytosis and significant IL- $1 \beta$ release by unprimed 
and LPS-primed THP-1 monocytes, we suggest that ROCKs are also involved in this inflammatory response.

Exposure of THP-1 monocytes to DWCNTs also mainly induced a significant increase of IL-6 secretion in LPS primed THP- 1 while a significant increase was only measured after $50 \mu \mathrm{g} / \mathrm{mL}$ exposure in unprimed THP-1 cell supernatants. Some authors have previously shown that IFN- $\gamma$ and TNF- $\alpha$ are implicated in IL-6 and IL-6 receptor modulation (Sanceau et al., 1991). IL-1 $\beta$ may have induced TNF- $\alpha$ secretion in THP-1 monocytes as it was previously shown in human mononuclear cells in vitro by Ikejima and colleagues (Ikejima et al., 1990). The observed IL-1 $\beta$ and TNF- $\alpha$ secretion after $6 \mathrm{~h}$ of exposure of THP- 1 cells to DWCNTs may have induced a significant increase of IL- 6 secretion after $24 \mathrm{~h}$ of exposure. IL-1 $\beta$ and TNF- $\alpha$ secretion may have activated the B-cell specific transcription factor NF- $\kappa \mathrm{B}$ and consequently pro-inflammatory secretion of IL- 6 and IL- 8 as previously described (Bonizzi and Karin, 2004). IL-6 is known to play an important role in monocytic cell differentiation (Chomarat et al., 2000). Moreover, we also measured very significant amounts of IL-10 at the highest DWCNT concentration. IL-10 may also promote monocyte differentiation in macrophage-like cells as previously shown by Allavena and colleagues (Allavena et al., 1998). We therefore hypothesized that DWCNTs, as observed after exposure to the highest concentration, mimic IFN- $\gamma$ effects and act as monocyte-macrophage activators.

\section{Conclusions}

In conclusion, our experiments showed that DWCNTs could modify monocyte phenotype also inducing a strong inflammatory response despite no decrease in cell viability. Thus, these DWCNTs could also potentially have a significant impact on the innate immune system. These properties must be cautiously taken into account especially in public health or nanomedicine issues. Due to the specific nature of the DWCNTs used in this work, these results may be extrapolated to both SWCNTs and MWCNTs in general.

\section{Declaration of interest statement}

This work was supported by a grant of the French Ministry of Defence for the research program NANO-HF. All authors declare that they have no competing interests, and are solely responsible for the content and writing of this publication.

\section{Acknowledgement}

The authors thank Edgar Gentilhomme for his technical assistance.

\section{Appendix A. Supplementary data}

Supplementary data associated with this article can be found, in the online version, at http://dx.doi.org/10.1016/j.tox.2016.07.019.

\section{References}

Allavena, P., Piemonti, L., Longoni, D., Bernasconi, S., Stoppacciaro, A., Ruco, L., Mantovani, A., 1998. IL-10 prevents the differentiation of monocytes to dendritic cells but promotes their maturation to macrophages. Eur. J. Immunol. 28, 359-369.

Baughman, R.H., Zakhidov, A.A., De Heer, W.A., 2002. Carbon nanotubes-the route toward applications. Science 297, 787-792.

Bonizzi, G., Karin, M., 2004. The two NF-kappaB activation pathways and their role in innate and adaptive immunity. Trends Immunol. 25, 280-288.

Cao, Y., Roursgaard, M., Jacobsen, N.R., Moller, P., Loft, S., 2015. Monocyte adhesion induced by multi-walled carbon nanotubes and palmitic acid in endothelial cells and alveolar-endothelial co-cultures. Nanotoxicology 1-10.
Chomarat, P., Banchereau, J., Davoust, J., Palucka, A.K., 2000. IL-6 switches the differentiation of monocytes from dendritic cells to macrophages. Nat. Immunol. 1, 510-514.

Daigneault, M., Preston, J.A., Marriott, H.M., Whyte, M.K., Dockrell, D.H., 2010. The identification of markers of macrophage differentiation in PMA-stimulated THP-1 cells and monocyte-derived macrophages. PLoS One 5, e8668.

De Nicola, M., Mirabile Gattia, D., Traversa, E., Ghibelli, L., 2013. Maturation and demise of human primary monocytes by carbon nanotubes. J. Nanoparticle Res. $15,1-15$.

Elgrabli, D., Dachraoui, W., Menard-Moyon, C., Liu, X.J., Begin, D., Begin-Colin, S. Bianco, A., Gazeau, F., Alloyeau, D., 2015. Carbon nanotube degradation in macrophages: live nanoscale monitoring and understanding of biological pathway. ACS Nano 9, 10113-10124.

Fiorito, S., Flahaut, E., Rapino, S., Paolucci, F., Andreola, F., Moroni, N., Pittaluga, E., Zonfrillo, M., Valenti, G., Mastrofrancesco, A., Groppi, F., Sabbioni, E., Bakalis, E., Zerbetto, F., Serafino, A., 2014. Redox active Double wall carbon nanotubes show intrinsic anti-proliferative effects and modulate autophagy in cancer cells. Carbon 78, 589-600.

Flahaut, E., Bacsa, R., Peigney, A., Laurent, C., 2003. Gram-scale CCVD synthesis of double-walled carbon nanotubes. Chem. Commun. (Camb) 1442-1443.

Flahaut, E., Durrieu, M.C., Remy-Zolghadri, M., Bareille, R., Baquey, C., 2006. Investigation of the cytotoxicity of CCVD carbon nanotubes towards human umbilical vein endothelial cells. Carbon 44, 1093-1099.

Grecco, A.C., Paula, R.F., Mizutani, E., Sartorelli, J.C., Milani, A.M., Longhini, A.L. Oliveira, E.C., Pradella, F., Silva, V.D., Moraes, A.S., Peterlevitz, A.C., Farias, A.S., Ceragioli, H.J., Santos, L.M., Baranauskas, V., 2011. Up-regulation of T lymphocyte and antibody production by inflammatory cytokines released by macrophage exposure to multi-walled carbon nanotubes. Nanotechnology 22, 265103.

Grosse, Y., Loomis, D., Guyton, K.Z., Lauby-Secretan, B., El Ghissassi, F., Bouvard, V., Benbrahim-Tallaa, L., Guha, N., Scoccianti, C., Mattock, H., Straif, K., International Agency for Research on Cancer Monograph Working, G., 2014. Carcinogenicity of fluoro-edenite, silicon carbide fibres and whiskers, and carbon nanotubes. Lancet Oncol. 15, 1427-1428.

Hamilton Jr., R.F., Wu, Z., Mitra, S., Shaw, P.K., Holian, A., 2013. Effect of MWCNT size, carboxylation, and purification on in vitro and in vivo toxicity, inflammation and lung pathology. Part Fibre Toxicol. 10, 57.

Haniu, H., Saito, N., Matsuda, Y., Kim, Y.A., Park, K.C., Tsukahara, T., Usui, Y., Aoki, K., Shimizu, M., Ogihara, N., Hara, K., Takanashi, S., Okamoto, M., Ishigaki, N., Nakamura, K., Kato, H., 2011. Elucidation mechanism of different biological responses to multi-walled carbon nanotubes using four cell lines. Int. J. Nanomed. 6, 3487-3497.

ISO, 2008. ISO/TS 27687:2008 - Nanotechnologies - Terminology and definitions for nano-objects-Nanoparticle, nanofibre and nanoplate.

Ikejima, T., Okusawa, S., Ghezzi, P., Van Der Meer, J.W., Dinarello, C.A., 1990. Interleukin-1 induces tumor necrosis factor (TNF) in human peripheral blood mononuclear cells in vitro and a circulating TNF-like activity in rabbits. J. Infect. Dis. 162, 215-223.

Kanno, S., Hirano, S., Chiba, S., Takeshita, H., Nagai, T., Takada, M., Sakamoto, K., Mukai, T., 2015. The role of Rho-kinases in IL-1beta release through phagocytosis of fibrous particles in human monocytes. Arch. Toxicol. 89, 73-85.

Kolosnjaj-Tabi, J., Just, J., Hartman, K.B., Laoudi, Y., Boudjemaa, S., Alloyeau, D., Szwarc, H., Wilson, L.J., Moussa, F., 2015. Anthropogenic carbon nanotubes found in the airways of Parisian children. EBioMedicine 2, 1697-1704.

Lanone, S., Rogerieux, F., Geys, J., Dupont, A., Maillot-Marechal, E., Boczkowski, J., Lacroix, G., Hoet, P., 2009. Comparative toxicity of 24 manufactured nanoparticles in human alveolar epithelial and macrophage cell lines. Part Fibre Toxicol. 6, 14.

Laverny, G., Casset, A., Purohit, A., Schaeffer, E., Spiegelhalter, C., De Blay, F., Pons, F., 2013. Immunomodulatory properties of multi-walled carbon nanotubes in peripheral blood mononuclear cells from healthy subjects and allergic patients. Toxicol. Lett. 217, 91-101.

Liu, Y., Zhao, Y., Sun, B., Chen, C., 2013. Understanding the toxicity of carbon nanotubes. Acc. Chem. Res. 46, 702-713.

Meng, J., Li, X., Wang, C., Guo, H., Liu, J., Xu, H., 2015. Carbon nanotubes activate macrophages into a M1/M2 mixed status: recruiting naive macrophages and supporting angiogenesis. ACS Appl. Mater. Interfaces 7, 3180-3188.

Methe, H., Kim, J.O., Kofler, S., Nabauer, M., Weis, M., 2005. Statins decrease Toll-like receptor 4 expression and downstream signaling in human CD14+ monocytes. Arterioscler. Thromb. Vasc. Biol. 25, 1439-1445.

Meunier, E., Coste, A., Olagnier, D., Authier, H., Lefevre, L., Dardenne, C., Bernad, J., Beraud, M., Flahaut, E., Pipy, B., 2012. Double-walled carbon nanotubes trigger IL-1 beta release in human monocytes through Nlrp3 inflammasome activation. Nanomedicine 8, 987-995.

Miozzi, E., Rapisarda, V., Marconi, A., Costa, C., Polito, I., Spandidos, D.A., Libra, M., Fenga, C., 2016. Fluoro-edenite and carbon nanotubes: the health impact of 'asbestos-like' fibres. Exp. Ther. Med. 11, 21-27.

Moeenrezakhanlou, A., Shephard, L., Lam, L., Reiner, N.E., 2008. Myeloid cell differentiation in response to calcitriol for expression CD11b and CD14 is regulated by myeloid zinc finger- 1 protein downstream of phosphatidylinositol 3-kinase. J. Leukoc. Biol. 84, 519-528.

Mundra, R.V., Wu, X., Sauer, J., Dordick, J.S., Kane, R.S., 2014. Nanotubes in biological applications. Curr. Opin. Biotechnol. 28, 25-32.

Ong, L.C., Chung, F.F., Tan, Y.F., Leong, C.O., 2014. Toxicity of single-walled carbon nanotubes. Arch. Toxicol. 
Pahl, H.L., Scheibe, R.J., Zhang, D.E., Chen, H.M., Galson, D.L., Maki, R.A., Tenen, D.G. 1993. The proto-oncogene PU.1 regulates expression of the myeloid-specific CD11b promoter. J. Biol. Chem. 268, 5014-5020.

Park, E.J., Cho, W.S., Jeong, J., Yi, J., Choi, K., Park, K., 2009. Pro-inflammatory and potential allergic responses resulting from $B$ cell activation in mice treated with multi-walled carbon nanotubes by intratracheal instillation. Toxicology 259, 113-121.

Pescatori, M., Bedognetti, D., Venturelli, E., Menard-Moyon, C., Bernardini, C., Muresu, E., Piana, A., Maida, G., Manetti, R., Sgarrella, F., Bianco, A., Delogu, L.G., 2013. Functionalized carbon nanotubes as immunomodulator systems. Biomaterials 34, 4395-4403.

Pondman, K.M., Sobik, M., Nayak, A., Tsolaki, A.G., Jakel, A., Flahaut, E., Hampel, S. Ten Haken, B., Sim, R.B., Kishore, U., 2014. Complement activation by carbon nanotubes and its influence on the phagocytosis and cytokine response by macrophages. Nanomedicine 10, 1287-1299.

Raffa, V., Ciofani, G., Vittorio, O., Riggio, C., Cuschieri, A., 2010. Physicochemical properties affecting cellular uptake of carbon nanotubes. Nanomedicine (Lond) $5,89-97$.

Sanceau, J., Wijdenes, J., Revel, M., Wietzerbin, J., 1991. IL-6 and IL-6 receptor modulation by IFN-gamma and tumor necrosis factor-alpha in human monocytic cell line (THP-1). Priming effect of IFN-gamma. J. Immunol. 147, 2630-2637.
Sauer U.G. Aumann, A., Ma-Hock, L., Landsiedel, R., Wohlleben, W., 2015. Influence of dispersive agent on nanomaterial agglomeration and implications for biological effects in vivo or in vitro. Toxicol. In Vitro 29, 182-186.

Steinbach, F. Thiele, B., 1994. Phenotypic investigation of mononuclear phagocytes by flow cytometry. J. Immunol. Methods 174, 109-122.

Tsuchiya, S., Kobayashi, Y., Goto, Y., Okumura, H., Nakae, S., Konno, T., Tada, K., 1982. Induction of maturation in cultured human monocytic leukemia cells by a phorbol diester. Cancer Res. 42, 1530-1536.

Turabekova, M., Rasulev, B., Theodore, M., Jackman, J., Leszczynska, D., Leszczynski, J., 2014. Immunotoxicity of nanoparticles: a computational study suggests that CNTs and C60 fullerenes might be recognized as pathogens by Toll-like receptors. Nanoscale 6, 3488-3495.

Yamaguchi, A., Fujitani, T., Ohyama, K., Nakae, D., Hirose, A., Nishimura, T., Ogata, A. 2012. Effects of sustained stimulation with multi-wall carbon nanotubes on immune and inflammatory responses in mice. J. Toxicol. Sci. 37, 177-189.

Yang, M., Flavin, K., Kopf, I., Radics, G., Hearnden, C.H., Mcmanus, G.J., Moran, B., Villalta-Cerdas, A., Echegoyen, L.A., Giordani, S., Lavelle, E.C., 2013. Functionalization of carbon nanoparticles modulates inflammatory cell recruitment and NLRP3 inflammasome activation. Small 9, 4194-4206.

Yang, J., Zhang, L., Yu, C., Yang, X.F., Wang, H., 2014. Monocyte and macrophage differentiation: circulation inflammatory monocyte as biomarker for inflammatory diseases. Biomark. Res. 2, 1. 